\title{
Trichinella spiralis in a cougar (Puma concolor) hunted by poachers in Chile
}

\author{
Trichinella spiralis em um puma (Puma concolor) caçado por caçadores furtivos \\ no Chile
}

\begin{abstract}
Diana Maritza Echeverry ${ }^{1}$ (D); Adriana Milena Santodomingo Santodomingo ${ }^{1}$ (D); Richard Said Thomas ${ }^{1}$ (D); Jorge González-Ugás²; Pablo Oyarzún-Ruiz iㅜ; María Carolina Silva-de la Fuente ${ }^{3}$ (D); Carlos Landaeta-Aqueveque ${ }^{1 *}$ (1)

\author{
${ }^{2}$ Unidad de Zoonosis y Control de Vectores de Interés Sanitario, Secretaría Regional Ministerial de Salud Ñuble, Chile \\ ${ }^{3}$ Facultad de Ciencias Veterinarias, Universidad Austral de Chile, Valdivia, Los Ríos, Chile
}

${ }^{1}$ Facultad de Ciencias Veterinarias, Universidad de Concepción, Chillán, Ñuble, Chile
\end{abstract}

\begin{abstract}
How to cite: Echeverry DM, Santodomingo AM, Thomas RS, González-Ugás J, Oyarzún-Ruiz P, Silva-de la Fuente MC, et al. Trichinella spiralis in a cougar (Puma concolor) hunted by poachers in Chile. Braz J Vet Parasitol 2021; 30(3): e002821. https://doi. org/10.1590/S1984-29612021033
\end{abstract}

\begin{abstract}
Trichinellosis is a zoonosis caused by nematodes of the Trichinella genus, of which 10 species have been described. Species identification when larvae is found is only possible using molecular tools. Meat from pigs and game animals not subjected to veterinary inspection are the main sources of human infections. The hunting of native carnivores is prohibited in Chile due to conservation issues and the fact that those animals favor pest control. The illegal hunting of a cougar (Puma concolor) occurred in September 2020. Herein, the molecular identification of Trichinella larvae, by analyzing nuclear (expansion segment V) and mitochondrial (cytochrome C oxidase subunit I) sequences are described. Both the amplification of the expansion segment $V$ region and the phylogenetic analysis of a segment of a fragment of the cytochrome c-oxidase subunit I sequence confirmed that the larvae belonged to $T$. spiralis. The case described herein represents the first evidence of illegal hunting of a protected mammal infected with Trichinella in Chile, highlighting the 'One Health' perspective to face this disease in the rural-sylvatic interphase.

Keywords: Trichinella, Puma concolor, game animal, One Health, Chile, zoonoses.

\section{Resumo}

A triquinelose é uma doença causada por nematoides do gênero Trichinella. Dez espécies foram descritas. A identificação das espécies a partir das larvas só foi possível com ferramentas moleculares. O abate doméstico de suínos e o consumo de animais de caça, sem inspeção veterinária, são as principais fontes de infecção humana. A caça de carnívoros nativos é proibida no Chile por questões de conservação e pelo fato de que esses animais favorecem o controle de pragas. A caça ilegal de um puma (Puma concolor) aconteceu em setembro de 2020. No Chile, a identificação molecular de larvas de Trichinella, obtida pelo exame de sequências nucleares (segmento de expansão V) e mitocondriais (citocromo C oxidase subunidade I) são descritas. Tanto a amplificação da região do segmento de expansão $V$ quanto a análise filogenética de um segmento de um fragmento da sequência da subunidade I da Citocromo c-oxidase, confirmaram que as larvas pertenciam a $T$. spiralis. O caso aqui descrito representa a primeira evidência de caça ilegal de um mamífero protegido infectado com Trichinella no Chile, destacando a perspectiva de "Saúde Única" para enfrentar esta doença na interfase rural-silvestre.
\end{abstract}

Palavras-chave: Trichinella, Puma concolor, animal de caça, Saúde Única, Chile, zoonoses.

Received February 22, 2021. Accepted March 22, 2021.

Financial support: This study was funded by the Fondo Nacional de Desarrollo Científico y Tecnológico, Chile ANID/FONDECYT (grant number: 11170294).

*Corresponding author: Carlos Landaeta-Aqueveque. E-mail: clandaeta@udec.cl 


\section{Introduction}

Trichinellosis is a disease present in all continents except Antarctica (Korhonen et al., 2016). A total of 10 species and three genotypes that have not yet been identified as distinct species have been reported around the world (Korhonen et al., 2016; Sharma et al., 2020). Two main cycles have been described: first is the domestic cycle, which encompasses pigs, dogs, cats, and rats as the main hosts; second, the wild cycle maintained in nature by wild carnivore and omnivore animals by predation, scavenging and cannibalism. Both cycles can be connected by ubiquitous species such as rats and other synanthropic animals (Pozio, 2000); as well, some species in the wild cycle can serve as the direct source of infection for humans after hunting and consuming game animals (García et al., 2005; Tryland et al., 2014; Fichi et al., 2015). Two Trichinella species are circulating in South America, mainly in Argentina: T. spiralis and T. patagoniensis (Ribicich et al., 2020). As well, the cougar (Puma concolor), wild boar (Sus scrofa), fox (Lycalopex gymnocercus gracilis), opossum (Didelphis albiventris), sea lion (Otaria flavescens), armadillo (Chaetophractus villosus), and pericote (Graomys centralis) have been described as wild hosts of Trichinella in either sylvatic or agricultural environments (Minoprio \& Abdon, 1967; Ribicich et al., 2020). Trichinella spiralis is the most widespread species of the genus and present both domestic and sylvatic cycles. Trichinella patagoniensis is the only species in South America that has not been found in the domestic environment; the cougar is its sole reported host species (Krivokapich et al., 2008, 2012).

The hunting of game animals is described as a source of Trichinella infection in humans, especially when game animals are not protected, as is the case for wild boars (García et al., 2005; Fichi et al., 2015). Conversely, hunting and consequent infection is less expected when game animals are protected, as occurs in Chilean native carnivores (SAG, 2012).

Herein, we describe the findings and subsequent analysis associated with the remains of a cougar infected with Trichinella, which was confiscated because of illegal hunting. The aim of this study was to check the presence of Trichinella larvae in the cougar muscles, and identify the parasites at the species level by molecular analysis. The public health significance of this finding is discussed.

\section{Materials and Methods}

On September 11, 2020, after an anonymous call, workers from the Servicio Agrícola y Ganadero of Chile found the remains of a hunted cougar in Pemuco Commune, Nuble Region ( $36^{\circ} 58^{\prime} 35.60^{\prime \prime}$ S; $72^{\circ} 5^{\prime} 55.56^{\prime \prime}$ W). Hunters escaped carrying most of the meat and the skull, leaving the skin and some other remains (Figure 1).

The meat remains were examined in the Facultad de Ciencias Veterinarias, Universidad de Concepción. Meat was semi-cured and well preserved. Muscles samples were investigated to detect the presence of Trichinella larvae.

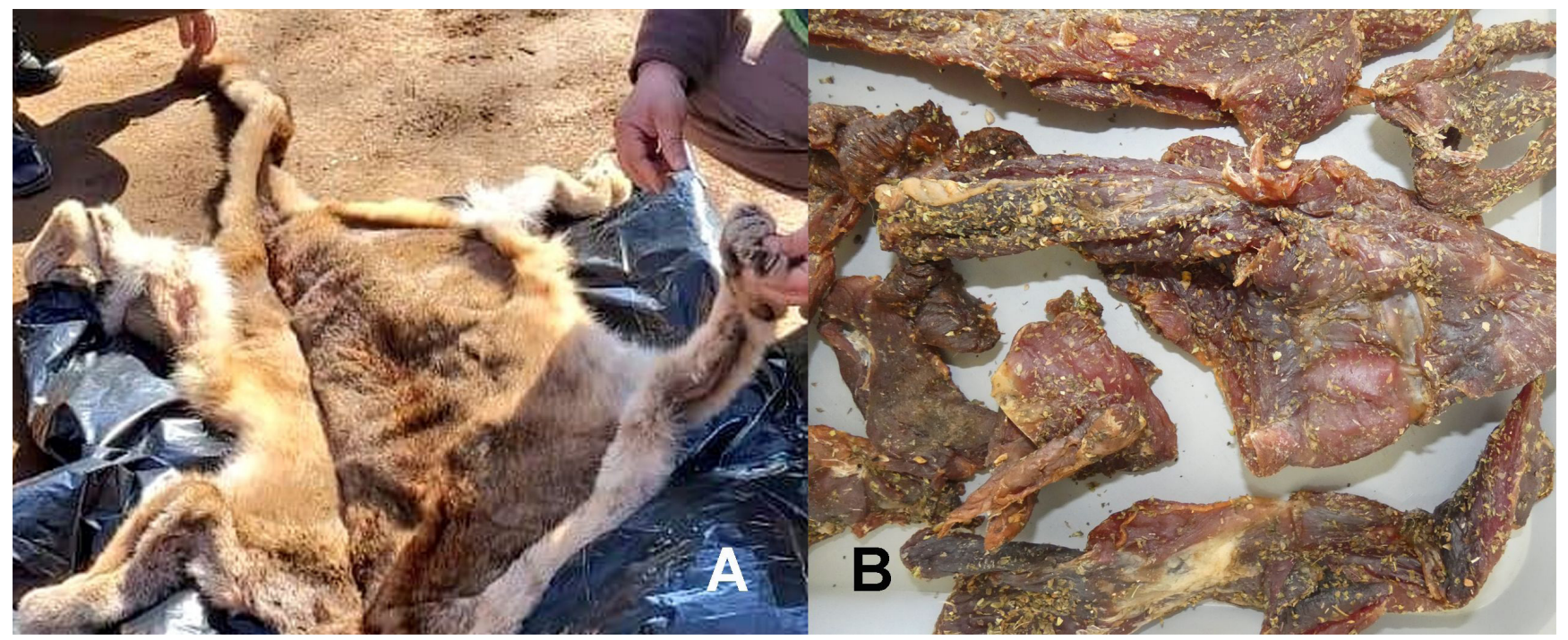

Figure 1. (A) The remains of the cougar found by the Servicio Agrícola y Ganadero (Photography: Servicio Agrícola y Ganadero, Nuble Region); (B) The meat remains after extracting its leather in the laboratory. 


\section{Parasitological and molecular analyses}

For the parasitological examination, $10 \mathrm{~g}$ of muscle (biceps brachii) were submitted to artificial digestion (Gajadhar et al., 2019), and the larvae were preserved in 96\% ethanol. For molecular identification, the DNA was extracted from a pool of 10 Trichinella larvae using the DNeasy Blood \& Tissue Kit (Qiagen $\left.{ }^{\circledR}\right)$, and 10 ng of DNA were used for identification at the species level by nested PCR of the expansion segment $V$ (ESV) following a modification of the protocol by Zarlenga et al. (1999). The DNA extracted from the meat was also used to detect Trichinella DNA, and $2 \mu \mathrm{L}$ were submitted to the same protocol. Reactions were performed in a final volume of $25 \mu \mathrm{L}$. The primer Ne (forward: TCTTGGTGGTAGTAGC and reverse: GCGATTGAGTTGAACGC. Zarlenga et al. (1999)) was used for the first PCR $(0.5 \mu \mathrm{M}$ of each primer), combined with $12.5 \mu \mathrm{L}$ of GoTaq Green Master Mix (Promega Corporation, Madison, WI, USA). DNA was amplified in a thermocycler (MultiGene ${ }^{\mathrm{TM}}$ OptiMax Thermal Cycler; Labnet) under the following cycling conditions: $95^{\circ} \mathrm{C} \times 1$ minute for initial denaturation; followed by 40 cycles of $95^{\circ} \mathrm{C} \times 30 \mathrm{sec} ; 56^{\circ} \mathrm{C} \times 1$ minute and $72^{\circ} \mathrm{C} \times 1$ minute; and a final extension of $72^{\circ} \mathrm{C} \times 2$ minutes. For the nested PCR, $0.5 \mu \mathrm{M}$ of primer I (forward: GTTCCATGTGAACAGCAGT and reverse: CGAAAACATACGACAACTGC. Zarlenga et al. (1999)) was used in a second PCR under the same previously described conditions, but with an annealing temperature of $55^{\circ} \mathrm{C}$.

For phylogenetic analysis in order to assess the position of the isolate within the $T$. spiralis species, the cytochrome c-oxidase subunit I (COI), DNA was amplified using $0.5 \mu \mathrm{M}$ of each primer, 5'-GAGCCGGAACAGGATGAACCATTT-3' and 5'-TTACGCCGGTTGGGATACCAAT-3' designed in this study, which amplified a fragment of $594 \mathrm{bp}$. These primers were designed using the software Amplifix 1.5.4 and on a sequence obtained from GenBank (KU321696). Reactions were performed in a final volume of $25 \mu \mathrm{L}$ with $12.5 \mu \mathrm{L}$ of GoTaq Green Master Mix (Promega Corporation). The PCR touchdown program was used and included an initial denaturation at $95^{\circ} \mathrm{C}$ for 2 minutes followed by six cycles, each cycle with denaturation at $95^{\circ} \mathrm{C}$ for $30 \mathrm{sec}$, annealing temperature decreases at $1^{\circ} \mathrm{C}$ per cycle from $60^{\circ} \mathrm{C}$ to $55^{\circ} \mathrm{C}$ for 1 minute, and extension at $72^{\circ} \mathrm{C}$ for 1 minute. Then, the protocol was completed with 35 additional cycles at an annealing temperature of $55^{\circ} \mathrm{C}$. A final extension at $72^{\circ} \mathrm{C}$ for 3 minutes was included at the end of the cycles. The PCR products were submitted to electrophoresis in agarose gel stained with SafeView ${ }^{\mathrm{TM}}$ (NBS Biologicals. UK) and visualized as previously described. Master mix without the DNA was the negative control and T. spiralis larvae obtained from a previous study (Landaeta-Aqueveque et al., 2015) was the positive control for all PCR.

\section{Phylogenetics analysis}

The obtained sequence (COI) was edited with ProSeq version (v)3 and compared with previous sequences by means of the Basic Local Alignment Search Tool (BLAST) (https://blast.ncbi.nlm.nih.gov). This sequence was also aligned with retrieved sequences from the NCBI database (https://www.ncbi.nlm.nih.gov/) using the ClustalW algorithm with MEGA 7.0 software (Kumar et al., 2016). Sequences were selected by preferring currently recognized Trichinella taxa and GenBank codes of the included sequences are shown in the phylogenetic tree in the results section (Korhonen et al., 2016). Maximum likelihood (ML) and Bayesian inference (BI) methods were used to construct the phylogenetic trees employing alignments for COI, given that these methods are based on models of molecular evolution.

Maximum likelihood (ML) analyses were run with IQ-TREE v 1.6.12 (Nguyen et al., 2015), and the Bayesian inference (BI) analyses in MrBayes v. 3.2.7. The best evolutionary model was chosen using the Bayesian Information Criterion (BIC), and employing the command "-m MFP+MERGE" for ML with ModelFinder (Kalyaanamoorthy et al., 2017), as well as the option "Iset nst=mixed rates=gamma" for BI in MrBayes.

For the ML analyses, rapid hill-climbing and stochastic disturbance methods were used with a robustness evaluation of the inferred tree with 1,000 ultrafast bootstrapping pseudo-replicates (Hoang et al., 2018). The Minh et al. (2013) criterion was employed to evaluate the ultrafast bootstrap: values $<70 \%$ are indicative of low statistical support, values between $70 \%-94 \%$ are indicative of medium statistical support, and values $\geq 95 \%$ are indicative of strong statistical support. For the Bl analyses, two independent tests of $10^{7}$ generations were performed with four Markov Chain Monte Carlo (MCMC) tests, with sampling trees produced for every 1,000 generations, and combined with eliminating the first $25 \%$ as burn-in. Tracer v 1.7.1 (Rambaut et al., 2018) was used to confirm the convergence of the MCMC chain, and Bayesian posterior probabilities (BPPs) $\geq 0.70$ (indicative of strong statistical support) were used as the criteria through which to evaluate the statistical strength of internal nodes. Capillaria gastrica was used as the external group for this analysis. 


\section{Report of human infection}

Chilean law requires that doctors immediately notify every human case of trichinellosis to authorities. These reports were examined in order to identify a possible outbreak caused by the consumption of this meat.

\section{Results and Discussion}

\section{Parasitological analysis}

The artificial digestion results revealed the presence of Trichinella larvae (about 10 larvae per gram). Larvae were coil shaped, but with low to null movement, suggesting low viability. Both Trichinella larvae and meat PCR amplified a product of $173 \mathrm{bp}$, corresponding to the ESV region of the large subunit ribosomal DNA of $T$. spiralis (Zarlenga et al., 1999). The PCR amplification of COI produced a segment of $594 \mathrm{bp}$. This sequence was included in GenBank with accession number MW471099. The BLAST analysis results shared between $99.29 \%$ and $99.82 \%$ identity with $T$. spiralis and $91.31 \%$ or less identity with other Trichinella species. The phylogenetic tree after ML and $\mathrm{BI}$ analysis (Figure 2) showed sequences of the same species grouped together and separated from the other species. It also showed the main clades (encapsulated and non-encapsulated, separately), validating the DNA fragment to identify the species. Thus, the phylogenetic tree confirmed the position of the examined larvae within the T. spiralis clade, next to a Poland isolate obtained from a wild boar (Sus scrofa). The ML and BI analyses showed the same topology and are presented in a single tree.

\section{Report of human infection}

Until November, no person presented with trichinellosis in the entire Nuble region, suggesting that either people in the region ate this meat and did not get ill (for instance, they ate well-cooked meat or the larvae were

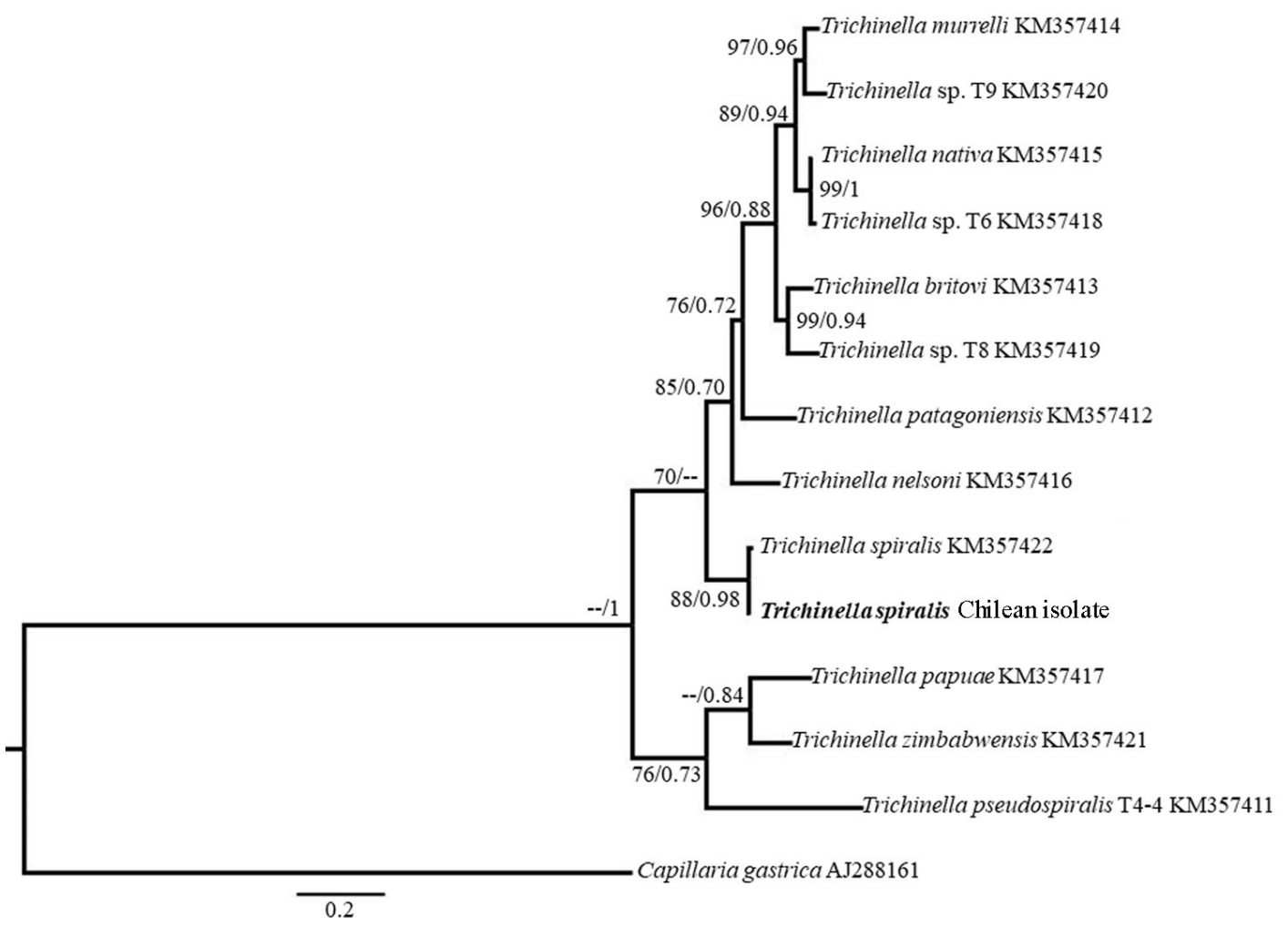

Figure 2. Bayesian (BI) and Maximum-Likelihood (ML) inference tree based on 1,297 nucleotides of the cytochrome c-oxidase subunit I DNA, reconstructed under the (i) ML substitution model: GTR+F+I (part 1- part 2) and HKY+F+G4 (part 3), and (ii) BI substitution model: $M_{138^{\prime}} M_{193^{\prime}} M_{200^{\prime}} M_{201^{\prime}} M_{40^{\prime}} M_{125}$ and $M_{203}$ (part 1 - part2), and $M_{201^{\prime}} M_{162^{\prime}} M_{203^{\prime}} M_{189^{\prime}} M_{136^{\prime}}$ and $M_{183^{\prime}}, M_{112}$ (part 3). The ML Bootstrap $(0-100)$ / BI posterior probability $(0-1)$ values are indicated for each node. Capillaria gastrica was used as the outgroup control. The sequence reported herein is presented in bold. 
not viable enough), no person ate this meat, or this meat was transported to another region without traceability. Given that larvae in cured meat can present with variable infectivity (Johne et al., 2020), and that the viability of larvae in the sample was low, the likelihood with which people become infected following the consumption of this meat is expected to be low.

\section{Further Considerations}

The hunting of animals is regulated in Chile, and native carnivores are protected in such a way that their hunting is prohibited (SAG, 2012). In addition, the slaughter of animals is also regulated, as domestic slaughter is not allowed by law (Chile, 2002). However, the law is usually disobeyed and people slaughter their animals. Alternatively, people submit a piece of meat to veterinary examination after the domestic slaughter and thus the prevention of human trichinellosis depends on this examination of the meat (Lisboa-Navarro et al., 2016). This examination, which at a minimum, is achieved by trichinoscopy in Chile, is performed not only in slaughterhouses, but also in veterinary clinics, which makes it easier for farmers to submit the meat to veterinary inspection.

Given all the above factors, the hunters of this cougar breached two laws: the hunting law and the slaughter law. However, one cannot state that the meat was not examined, as the typical veterinary examination does not identify the animal species being examined, it only looks for larvae. Therefore, hunters could declare that the meat belongs to another animal species.

Cougars and other felids have reportedly harbored Trichinella, as P. concolor was found to harbor T. spiralis (Landaeta-Aqueveque et al., 2015) in Chile. Elsewhere, P. concolor was shown to harbor T. patagoniensis in Argentina (Krivokapich et al., 2012); P. concolor coryi harbored T. spiralis and T. pseudospiralis in the United States (Reichard et al., 2015); P. concolor cougar harbored Trichinella nativa, T. pseudospiralis, Trichinella murrelli, and Trichinella T6 in Canada (Gajadhar \& Forbes, 2010). Similarly, Lynx canadensis harbored Trichinella T6 in Canada (Gajadhar \& Forbes, 2010), Lynx rufus Schreber, 1777 harbored T. britovi in Europe, and Felis silvestris Schreber, 1777 harbored T. britovi and T. spiralis in Europe (Pozio et al., 2009). Since only T. spiralis and T. patagoniensis have been reported in wild animals in South America, these were the expected species for this finding. Although no prevalence study has been reported in the cougar, a higher frequency of Trichinella infection than in other carnivore is expected because it is a top consumer in the food pyramid.

The case described herein provides the first evidence of illegal hunting of a protected mammal infected with Trichinella in Chile and highlights the need to reinforce education on disease prevention and the care of native fauna. Finally, this case underlines the 'One Health' perspective to face this disease in the rural-sylvatic interphase.

\section{Acknowledgements}

In memoriam: The authors dedicate this article to Daniel González-Acuña, who died during the final revision of this manuscript prior to submission, and who made significant contributions to this study, but could not read the final text.

This study was funded by the Fondo Nacional de Desarrollo Científico y Tecnológico, Chile ANID/FONDECYT (grant number: 11170294).

\section{References}

Chile. Ministerio de Salud - MINSAL. Norma general técnica sobre inspeccion medico veterinaria de las reses de abasto y de sus carnes y criterios para la calificación de aptitud para el consumo humano [online]. Chile: Ministerio de Salud; 2002 [cited 2020 Dec 29]. Available from: http://juridico1.minsal.cl/RESOLUCION_711_02.doc

Fichi G, Stefanelli S, Pagani A, Luchi S, De Gennaro M, Gómez-Morales MA, et al. Trichinellosis outbreak caused by meat from a wild boar hunted in an Italian region considered to be at negligible risk for Trichinella. Zoonoses Public Health 2015; 62(4): 285291. http://dx.doi.org/10.1111/zph.12148. PMid:25103623.

Gajadhar AA, Forbes LB. A 10-year wild life survey of 15 species of Canadian carnivores identifies new hosts or geographic locations for Trichinella genotypes T2, T4, T5, and T6. Vet Parasitol 2010; 168(1-2): 78-83. http://dx.doi.org/10.1016/j.vetpar.2009.10.012. PMid:19926223. 
Gajadhar AA, Noeckler K, Boireau P, Rossi P, Scandrett B, Gamble HR. International Commission on Trichinellosis: recommendations for quality assurance in digestion testing programs for Trichinella. Food Waterborne Parasitol 2019; 16: e00059. http://dx.doi. org/10.1016/j.fawpar.2019.e00059. PMid:32095629.

García E, Mora L, Torres P, Jercic MI, Mercado R. First record of human trichinosis in Chile associated with consumption of wild boar (Sus scrofa). Mem Inst Oswaldo Cruz 2005; 100(1): 17-18. http://dx.doi.org/10.1590/S0074-02762005000100003. PMid:15867957.

Hoang DT, Chernomor O, von Haeseler A, Minh BQ, Vinh LS. UFBoot2: improving the ultrafast bootstrap approximation. Mol Biol Evol 2018; 35(2): 518-522. http://dx.doi.org/10.1093/molbev/msx281. PMid:29077904.

Johne A, Filter M, Gayda J, Buschulte A, Bandick N, Nöckler K, et al. Survival of Trichinella spiralis in cured meat products. Vet Parasitol 2020; 287: 109260. http://dx.doi.org/10.1016/j.vetpar.2020.109260. PMid:33053490.

Kalyaanamoorthy S, Minh BQ, Wong TKF, von Haeseler A, Jermiin LS. ModelFinder: fast model selection for accurate phylogenetic estimates. Nat Methods 2017; 14(6): 587-589. http://dx.doi.org/10.1038/nmeth.4285. PMid:28481363.

Korhonen PK, Pozio E, La Rosa G, Chang BCH, Koehler AV, Hoberg EP, et al. Phylogenomic and biogeographic reconstruction of the Trichinella complex. Nat Commun 2016; 7(1): 10513. http://dx.doi.org/10.1038/ncomms10513. PMid:26830005.

Krivokapich SJ, Pozio E, Gatti GM, Prous CL, Ribicich M, Marucci G, et al. Trichinella patagoniensis n. sp. (Nematoda), a new encapsulated species infecting carnivorous mammals in South America. Int J Parasitol 2012; 42(10): 903-910. http://dx.doi. org/10.1016/j.ijpara.2012.07.009. PMid:22921601.

Krivokapich SJ, Prous CL, Gatti GM, Confalonieri V, Molina V, Matarasso H, et al. Molecular evidence for a novel encapsulated genotype of Trichinella from Patagonia, Argentina. Vet Parasitol 2008; 156(3-4): 234-240. http://dx.doi.org/10.1016/j. vetpar.2008.06.003. PMid:18650017.

Kumar S, Stecher G, Tamura K. MEGA7: Molecular Evolutionary Genetics Analysis Version 7.0 for Bigger Datasets. Mol Biol Evol 2016; 33(7): 1870-1874. http://dx.doi.org/10.1093/molbev/msw054. PMid:27004904.

Landaeta-Aqueveque C, Krivokapich S, Gatti GM, Prous CG, Rivera-Bückle V, Martín N, et al. Trichinella spiralis parasitizing Puma concolor: first record in wildlife in Chile. Helminthologia 2015; 52(4): 360-363. http://dx.doi.org/10.1515/helmin-2015-0057.

Lisboa-Navarro R, González J, Junod T, Melín-Coloma M, Landaeta-Aqueveque C. Conocimientos y prácticas sobre hidatidosis y triquinosis en usuarios y acompañantes del Hospital Comunitario de Salud Familiar El Carmen, Región del Biobío, Chile. Rev Chilena Infectol 2016; 33(4): 474-476. http://dx.doi.org/10.4067/S0716-10182016000400016. PMid:27905635.

Minh BQ, Nguyen MAT, von Haeseler A. Ultrafast approximation for phylogenetic bootstrap. Mol Biol Evol 2013; 30(5): $1188-1195$. http://dx.doi.org/10.1093/molbev/mst024. PMid:23418397.

Minoprio JL, Abdon HD. Factores ecológicos que determinan la Trichiniasis silvestre en el oeste de San Luis y en el este de Mendoza. An Soc Cient Argent 1967; 183: 19-30.

Nguyen L-T, Schmidt HA, von Haeseler A, Minh BQ. IQ-TREE: A fast and effective stochastic algorithm for estimating maximumlikelihood phylogenies. Mol Biol Evol 2015; 32(1): 268-274. http://dx.doi.org/10.1093/molbev/msu300. PMid:25371430.

Pozio E, Rinaldi L, Marucci G, Musella V, Galati F, Cringoli G, et al. Hosts and habitats of Trichinella spiralis and Trichinella britovi in Europe. Int J Parasito/ 2009; 39(1): 71-79. http://dx.doi.org/10.1016/j.ijpara.2008.06.006. PMid:18708065.

Pozio E. Factors affecting the flow among domestic, synanthropic and sylvatic cycles of Trichinella. Vet Parasitol 2000; 93(3-4): 241-262. http://dx.doi.org/10.1016/S0304-4017(00)00344-7. PMid:11099840.

Rambaut A, Drummond AJ, Xie D, Baele G, Suchard MA. Posterior summarization in Bayesian phylogenetics using Tracer 1.7. Syst Biol 2018; 67(5): 901-904. http://dx.doi.org/10.1093/sysbio/syy032. PMid:29718447.

Reichard MV, Criffield M, Thomas JE, Paritte JM, Cunningham M, Onorato D, et al. High prevalence of Trichinella pseudospiralis in Florida panthers (Puma concolor coryi). Parasit Vectors 2015; 8(1): 67. http://dx.doi.org/10.1186/s13071-015-0674-z. PMid:25649739.

Ribicich MM, Fariña FA, Aronowicz T, Ercole ME, Bessi C, Winter M, et al. A review on Trichinella infection in South America. Vet Parasitol 2020; 285: 109234. http://dx.doi.org/10.1016/j.vetpar.2020.109234. PMid:32949838.

Servicio Agrícola y Ganadero - SAG. Ley de Caza y su Reglamento [online]. Santiago: SAGE; 2012 [cited 2014 Dec 30 ]. Available from: http://www.sag.cl/sites/default/files/ley_caza_edicion2012.pdf

Sharma R, Thompson PC, Hoberg EP, Brad Scandrett W, Konecsni K, Harms NJ, et al. Hiding in plain sight: discovery and phylogeography of a cryptic species of Trichinella (Nematoda: Trichinellidae) in wolverine (Gulo gulo). Int J Parasitol 2020; 50(4): 277-287. http://dx.doi.org/10.1016/j.ijpara.2020.01.003. PMid:32171846.

Tryland M, Nesbakken T, Robertson L, Grahek-Ogden D, Lunestad BT. Human pathogens in marine mammal meat - A Northern perspective. Zoonoses Public Health 2014; 61(6): 377-394. http://dx.doi.org/10.1111/zph.12080. PMid:24344685.

Zarlenga DS, Chute MB, Martin A, Kapel CMO. A multiplex PCR for unequivocal differentiation of all encapsulated and nonencapsulated genotypes of Trichinella. Int J Parasito/ 1999; 29(11): 1859-1867. http://dx.doi.org/10.1016/S0020-7519(99)00107-1. PMid:10616932. 